\title{
ANALISIS FEASIBILITAS MEDICATION EVENT MONITORING SYSTEM CAP DALAM PENINGKATAN KEPATUHAN MINUM OBAT PADA ORANG DENGAN SKIZOFRENIA : A LITERATURE REVIEW
}

\author{
Alfunnafi' Fahrul Rizzal, ${ }^{1}$ Tuti Afriani, ${ }^{2}$ \\ ${ }^{1}$ Program Studi Magister, Fakultas Imu Keperawatan, Universitas Indonesia, \\ Depok \\ ${ }^{2}$ Fakultas IImu Keperawatan, Universitas Indonesia, Depok
}

\begin{abstract}
ABSTRAK
Pendahuluan: Pengobatan orang dengan skizofrenia memerlukan jangka waktu pengobatan yang panjang, meliputi terapi farmakologi maupun terapi psikososial. Kondisi ini memicu potensi terjadinya putus obat yang berakibat kekambuhan orang dengan skizofrenia. Berbagai upaya dilakukan untuk meningkatkan kepatuhan salah satunya dengan menggunakan teknologi. Salah satu inovasi teknologi tersebut adalah metode pengawasan kepatuhan menggunakan MEMS $\AA$ cap. Alat ini digunakan untuk melakukan pengawasan kepatuhan minum obat secara elektronik.

Metode: Metode penulisan menggunakan non systematic literature review.

Hasil: MEMS ${ }^{8}$ cap terbukti efektif digunakan di berbagai negara seperti di Eropa, Amerika, dan Asia dalam menjalankan fungsinya dalam pengawasan kepatuhan pengobatan klien skizofrenia.

Kesimpulan: Teknologi (MEMS®) cap merupakan solusi dalam meningkatkan upaya kepatuhan minum obat pada orang dengan skizofrenia dan memudahkan tenaga kesehatan dalam mengawasi penggunaan obat yang dianjurkan. Teknologi ini memberikan kemudahan dengan menyediakan layanan penentuan dosis obat, waktu pengobatan, dan alarm pengingat.
\end{abstract}

Kata kunci: Kepatuhan pengobatan , MEMS® cap, kekambuhan, Orang Dengan Skizofrenia (ODS). 


\begin{abstract}
Introduction: People with schizophrenia requires a long-term treatment, including pharmacologicaland psychosocial therapy. Drop- out from medication may happens and relapse of the sign and symptoms of schizophrenia may occurs $A$ variety of efforts applied to enhance compliance, including with the use of technology. technological innovation is developed for the supervision of compliance using MEMS ${ }^{\circledR}$ cap.. This tool is used to monitor compliance with medication electronically

Methods: Non systematic literature review method has used in this article.

Result: MEMS ${ }^{\circledR}$ cap proved effective in use in different countries such as in Europe, United States and Asia in carrying out its function in the supervision of compliance with the treatment in people with schizophrenia

Conclusion: Technology (MEMS $\AA$ ) cap is the solution in improving the compliance efforts of taking the drug in people with schizophrenia and facilitate health workers in supervising the use of the drug is recommended. This technology provides convenience by providing drug dose determination of service, time of treatment, and alarm reminder
\end{abstract}

\title{
Keywords: Medication Adherence, MEMS $\circledast$ cap, relapse, people with schizophrenia
}

\section{PENDAHULUAN}

Data Riset Kesehatan Dasar (Riskesdas) tahun 2013 menunjukkan bahwa angka gangguan jiwa berat atau skizofrenia di Indonesia mencapai presentase $0.17 \%$ per 1000 penduduk ${ }^{(1)}$. Jumlah tersebut menunjukkan bahwa gangguan jiwa merupakan fenomena yang perlu mendapatkan perhatian dalam penanganan dan pencegahan secara komprehensif.

Skizofrenia merupakan jenis gangguan psikotik dengan tanda gejala positif meliputi halusinasi dan delusi serta tanda gejala negatif meliputi kecemasan dan menarik diri ${ }^{(2)}$. Gangguan psikotik skizofrenia juga mempengaruhi kemampuan kognitif seperti ketidak mampuan mengingat dan berkomunikasi.

Orang dengan skizofrenia (ODS) akan mengalami gangguan kemampuan dalam merawat dirinya sendiri. Ketidakmampuan dalam menjalankan fungsi dan peran dalam kehidupan sehari-hari seperti merawat diri sendiri, tidak mampu mengambil keputusan, tidak mampu bekerja dan fungsi lainnya. Kondisi ini menyebabkan klien dengan skizofrenia memerlukan bantuan orang lain dalam menjalankan aktifitasnya sehari-hari agar tetap bertahan hidup. Bantuan yang dibutuhkan meliputi bantuan dalam kebersihan diri, pemenuhan nutrisi, hingga pengobatan sebagai upaya dalam mencapai kesembuhan ODS ${ }^{(3)}$.
Upaya pengobatan pada orang dengan skizofrenia membutuhkan proses waktu yang panjang termasuk upaya farmakologi dan terapi psikososial (4). ODS akan mendapatkan terapi dalam jangka waktu yang panjang. Terapi harus diberikan secara tepat dan disiplin untuk mendapatkan efek terapi yang terapeutik. Namun, kurun waktu terapi yang lama akan berpengaruh terhadap perilaku kepatuhan dalam menjalankan program pengobatan. Rasa bosan, putus asa, dan biaya yang harus dikeluarkan menurunkan motivasi untuk patuh terhadap pengobatan. Ketidakpatuhan pengobatan ini kemudian menyebabkan terjadinya kekambuhan pada ODS $^{(2)}$. Berbagai upaya untuk meningkatan kepatuhan terapi pada ODS dilakukan dengan tujuan untuk mencapai taraf terapeutik yang optimal. Upaya tersebut mulai bergeser dari upaya konvensional yang bertumpu hanya pada peran sumber daya manusia saja ke arah pengembangan teknologi yang mampu menunjang ketercapaian pengobatan.

Pengembangan teknologi menjadi sasaran dalam meningkatkan kepatuhan

ODS dalam menjalankan terapi. Pemantauan pengobatan secara elektronik dianggap sebagai inovasi teknologi informasi yang dapat diandalkan ${ }^{(5)(6)}$. Teknologi yang disebut Medication event Monitoring System (MEMS®) cap menjadi pilihan solusi dalam meningkatkan kepatuhan 
pengobatan pada $\operatorname{ODS}^{(7)}$. Beberapa penelitian yang di lakukan di Amerika Eropa dan Asia telah melakukan penelaahan kepatuhan terapeutik klien skizofrenia dengan menggunakan (MEMS®) cap(8) (9) (10) (11) (12).

Tujuan dari artikel ini adalah untuk menganalisa feasibilitas penggunaan (MEMS®) cap dalam meningkatkan kepatuhan pengobatan pada orang dengan skizofrenia (ODS).

\section{METOLOGI PENELITIAN}

Penulisan artikel ini merupakan penelaahan dari berbagai literatur seperti textbook dan artikel jurnal dari database pencarian Ebscohost, Proquest, Science Direct dengan menggunakan kata kunci "schizophrenia", "medication adherence", "MEMS cap in schizhophrenia". Referensi yang digunakan penulis terdiri atas textbook dan artikel jurnal. Metodologi penulisan artikel menggunakan penelusuran literature non sistematis (Non-systematic literature review).

\section{TINJAUAN LITERATUR}

bentuk $\begin{array}{ccc}\text { Skizofrenia } & \text { merupakan suatu } \\ \text { gangguan } & \text { psikosa yang }\end{array}$ mempengaruhi otak dan menimbulkan pikiran, persepsi, emosi, serta perilaku yang aneh dan terjadi perubahan neurobiologi pada otak yang persisten dan serius ${ }^{(13)}$. Tanda gejala skizofrenia juga khas yang terdiri dari tanda gejala positif dan negatif. Tanda gejala positif skizofrenia adalah munculnya halusinasi, delusi, pikiran kacau, dan perilaku agresif ${ }^{(14)}$. Sedangkan tanda gejala negatif skizofrenia yaitu munculnya perubahan afek atau emosi, kecenderungan menarik diri, distorsi kenyataan, serta kesulitan dalam membuat keputusan dan menjalin hubungan interaktif dengan orang lain $^{(15)}$.

Orang dengan skizofrenia akan mengalami perubahan yang hampir menyeluruh di dalam hidupnya meliputi perubahan kognitif, afektif, fisiologis, perilaku, dan sosial.

Penanganan skizofrenia sudah banyak dikembangkan oleh berbagai disiplin ilmu. Penelitian-penelitian yang mengulas dan mencari solusi tentang penanganan skizofrenia dapat ditemukan dalam publikasi ilmiah. Perkembangan penanganan skizofrenia juga bertujuan untuk mengetahui tentang keberhasil dari terapi-terapi tersebut. Salah satu penanganan skizofrenia adalah pemberian psikofarmaka. Terapi ini diberikan sesuai dari hasil pemeriksaan dan diagnose dari tanda gejala yang ditemukan dari hasil pemeriksaan klien. Pemberian terapi psikofarmaka ini harus memenuhi kriteria dalam cara pemberiaanya termasuk kepatuhan minum obat di dalamnya ${ }^{(16)}$.

Kepatuhan minum obat pada ODS merupakan kepatuhan klien dalam menjalankan rejimen pengobatan sesuai dengan saran dokter, perawat, dan tenaga kesehatan yang tergabung dalam tim pengobatan ${ }^{(17)}$. Beberapa faktor yang menyebabkan ketidakpatuhan klien dalam mengikuti terapi berdasarkan penelitian Karmila (2016) adalah faktor obat, faktor dokter, faktor lingkungan, dan yang tertinggi adalah faktor keluarga ${ }^{(18)}$. Faktor keluarga menjadi faktor penyebab tertinggi berkaitan dengan persepsi

keluarga yang menganggap jika pengobatan bisa dihentikan apabila tanda dan gejala ODS sudah tidak ditemukan lagi. Akibatnya penghentian pengobatan atau (drop-out) obat yang bukan sesuai dari saran dokter dan tenaga kesehatan, menyebabkan kekambuhan pada orang dengan skizofrenia(19).

Fenomena kekambuhan akibat droup-out obat yang banyak terjadi dan memberikan dampak negatif pada ODS, mendorong ide untuk penyelesaian

masalah dengan memanfaatkan berkembangnya teknologi. Upaya dalam meningkatkan kepatuhan minum obat juga mendorong inovasi dalam pembuatan alat bantu yang bertujuan untuk meningkatkan kepatuhan minum obat. Medication event Monitoring System (MEMS®) cap

merupakan merupakan alat yang dikembangbangkan dengan tujuan peningkatkan kepatuhan minum obat pada klien skizofrenia. Alat ini pertama kali diperkenalkan pada tahun 1997 di negara Eropa. (MEMS®) cap mulai 
dikenalkan dan meluas di beberapa negara seperti USA pada tahun 2002 dan Israel pada tahun 2003 dan sudah meluas di berbagai negara lainnya. Alat ini bekerja dengan cara mengumpulkan data kepatuhan secara elektronik terintegrasi dan secara otomatis menjadi alat penyimpanan obat. Sehingga alat ini akan memberikan informasi berupa pengingat atau alarm kepada user mengenai dosis, waktu, rute, serta jumlah obat yang tersedia $^{(9)}$.

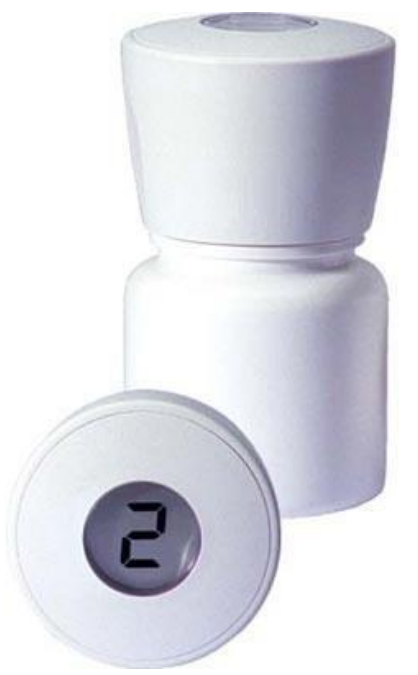

Gambar 1. (MEMS®) cap device

Prosedur dalam menggunakan alat ini adalah, setiap pasien menerima device dari seorang perawat berbentuk sebuah botol pil dengan cap yang mencatat waktu dan tanggal setiap pembukaan dan penutupan botol. MEMS $\AA$; memberikan pengingat, timer atau alarm untuk pasien. Perawat memberikan informasi kepada setiap pasien tentang protokol dan prosedur pemantauan. Obat yang telah diresepkan secara keseluruhan akan dimasukkan dalam alat seperti pada Gambar 1. Setelah itu alat akan di atur mengenai waktu dan jumlah obat yang di konsumsi sesuai petunjuk resep. Layar LCD yang tertera membantu pemilik dalam mengingat waktu, jumlah, serta sisa obat yang harus diminum ${ }^{(7)}$.

\section{PEMBAHASAN}

Meningkatkan kepatuhan ODS dalam pengobatan dilakukan melalui beberapa metode pendekatan, diantaranya : pendidikan, akomodasi faktor lingkungan dan sosial, perubahan model terapi dan meningkatkan interaksi

professional kesehatan dan klien (Australian college of pharmacy practice (2001). Terdapat beberapa cara dalam meningkatkan klien dalam pengobatan antara lain : menumbuhkan kepatuhan dengan mengembangkan tujuan kepatuhan, mengembangkan strategi untuk merubah perilaku dan mempertahankannya, mengembangkan kognitif, dan dukungan sosial( ${ }^{(20)}$. Menurut Highashi et. al, (2015) strategi dalam kepatuhan minum obat harus memenuhi strategi, antara lain : ambil obat yang sudah diresepkan dokter, minum obat sesuai identitas yang tepat, dosis, waktu, masih menggunakan obat meskipun gejala berkurang atau bahkan sudah hilang, strategi untuk mengingat obat, menggunakan alarm/ponsel, melakukan kontrol perawatan, serta mematuhi anjuran tenaga kesehatan sesuai dengan psikoterapi yang diberikan. ${ }^{(21)}$

Perencanaan pengobatan harus sudah di persiapkan apabila klien keluar rumah sakit untuk menunjang keberhasilan terapi yang diberikan salah satunya dengan menyiapkan pengawas minum obat (PMO) untuk klien. Beberapa tugas yang dilakukan PMO termasuk mengambil obat yang sudah diresepkan dokter, menyiapkan sesuai dosis, waktu, dan rute pemberian (Wardani, 2009). Tugas ini tentunya akan menjadi masalah tersendiri bagi keluarga yang tidak memiliki banyak waktu secara terus menerus mendampingi pasien karena suatu alasan tertentu. Kondisi keluarga yang tidak mampu mendukung klien dalam pemenuhan pengobatan secara utuh, memicu upaya lain dalam memenuhi kepatuhan minum obat pada klien skizofrenia. Model modifikasi kondisi dengan memanfaatkan teknologi sudah banyak dikembangkan untuk keperluan kesehatan.

Efektifitas penggunaan (MEMS®) cap dalam meningkatkan kepatuhan pengobatan klien skizofrenia sudah dilakukan berbagai penelitian. Indikator 
yang digunakan adalah ketepatan dosis, ketepatan waktu, ketepatan rute, dan kepatuhan klien untuk minum obat secara paripurna Brain et al. (2014) menjelaskan melalui penelitiannya bahwa kemampuan kepatuhan klien meningkat dengan menggunakan (MEMS®) cap. Hal ini berdasarkan kemudahan klien dalam menggunakan alat meliputi dikumentasi variabel sosiodemografi, rejimen pengobatan yang diterima, serta penggunaan antipsikotik lainnya. Para psikiater melihat kemajuan klien setiap bulan melalui informasi yang dikirimkan melalui server dari alat yang dimiliki masing masing klien.

Ketepatan dosis pemberian merupakan salah satu keuntungan dari penggunaan (MEMS $\AA$ ) cap. Pemberian dosis yang tepat menunjang efek

terapeutik yang didapatkan dari pengobatan. Berdasarkan studi yang dilakukan oleh Acosta et al. (2013), selain kemudahan penggunaan oleh user, ketepatan dalam pemberian dosis obat menjadi kelebihan penggunaan (MEMS®) cap. Kondisi ODS yang menjalani terapi jangka panjang memicu peningkatan pemberian dosis $^{(7)}$. Sehingga dengan menggunakan (MEMS®) cap akan meminimalisir ketidaktepatan dosis obat dikarenakan kebosanan user untuk melihat ulang petunjuk pengobatan ${ }^{(19)}$.

Selain dosis yang kurang tepat, kesalahan dalam waktu pemberian obat seringkali ditemukan dalam pengobatan klien skizofrenia berkaitan dengan kurun waktu pemberian medikasi dalam jangka panjang. Hal ini dapat diantisipasi dengan menggunakan (MEMS®) cap. Ketepatan waktu pemberian merupakan salah satu fasilitas yang disediakan oleh (MEMS®) cap (Acosta, 2013). Klien dengan pemberian waktu pengobatan yang kurang tepat akan memicu kekambuhan. Dengan demikian pemberian terapi dengan waktu yang tepat akan mencegah terjadinya kekambuhan pada klien skizofrenia.

Pemanfaatan (MEMS®) cap mampu meringankan perawat dalam melakukan tugas pemantauan obat pada ODS setelah keluar dari RS. Aspek efisiensi waktu perawat dalam melakukan pengawasan dapat berkurang hingga 40\%(22). Efisiensi waktu tersebut meliputi waktu dalam memberikan obat, dokumentasi yang dilakukan, serta memacu klien untuk lebih sadar dan mandiri tentang keperluan pengobatannya Efisiensi waktu ini dapat dimanfaatkan perawat agar lebih banyak waktu untuk melakukan perawatan langsung ,

meningkatkan pengelolaan terapi keperawatan kepada klien secara optimal(23).

(MEMS®) cap meningkatkan efisiensi pemantauan obat dalam proses keperawatan. Hasil Studi dari Callen et al., (2013) menyatakan bahwa perawat merasa lebih percaya diri dengan menggunakan teknologi (MEMS $\AA$ ) cap karena meminimalisir kesalahan dalam pemberian obat kepada pasien. Selain itu aplikasi ini terintegrasi dengan sistem

catatan informasi klinis berbasis elektronik. Sehingga pemantauan berkala melalui teknologi ini dapat diaplikasikan oleh dokter sebagai pemberi resep, perawat sebagai pemberi petunjuk dan pengawas pengobatan di rumah sakit, serta keluarga sebagai sistem pendukung pengobatan. Fasilitas ini tentu memberikan banyak manfaat baik bagi klien, perawat, maupun keluarga karena dapat digunakan pada pelayanan

kesehatan rumah sakit maupun komunitas $^{(6)}$.

Pemanfaatan teknologi (MEMS $\AA$ ) cap masih belum dapat diaplikasikan di Indonesia. Hal ini berkaitan dengan harga dari alat yang kurang terjangkau bagi masyarakat luas. Alat ini memerlukan penggunaan sistem elektronik terintegrasi dengan database yang belum tersedia di Indonesia. Sumberdaya manusia dalam hal ini perawat harus mampu untuk menguasai peralatan ini yang masih menggunakan petunjuk penggunaan

berbahasa inggris. Selain itu sosiodemografi klien skizofrenia di Indonesia cenderung pada ekonomi rendah dan kurangnya kemampuan menggunakan teknologi yang baru. Potensi pengembangan teknologi ini dapat dilakukan melalui aplikasi mobile seperti ApoteCare ${ }^{\circledR}$ karya mahasiswa Universitas Indonesia yang memiliki 
kesamaan fungsi pemantauan meliputi penentuan dosis obat, waktu pemberian, dan rute pemberian.

\section{KESIMPULAN}

Kepatuhan minum obat pada klien skizofrenia merupakan salah satu faktor yang menunjang keberhasilan dalam kesembuhan klien. Klien skizofrenia memiliki kurun waktu pengobatan yang panjang sehingga memiliki resiko tinggi dalam kejadian drop-out atau putus obat. Akibat yang ditimbulkan dari putus obat adalah kekambuhan pasien dan peningkatan dosis pengobatan selanjutnya. Untuk itu klien skizofrenia harus benar benar dipastikan dalam kepatuhan pengobatan yang diterima.

Salah satu metode dalam meningkatkan upaya kepatuhan minum obat adalah dengan menyediakan Pengawas Minum Obat (PMO) bagi klien. PMO dibentuk dari keluarga sebagai unit terdekat dari klien. Sebenarnya metode ini efektif, namun seringkali hasilnya tidak sesuai dari harapan. Hal ini dipengaruhi oleh,

ketidakmampuan keluarga dalam mendampingi pasien dengan suatu alasan tertentu.

Teknologi (MEMS®) cap merupakan salah satu solusi dalam meningkatkan upaya kepatuhan minum obat ODS dan memudahkan tenaga kesehatan dalam mengawasi penggunaan obat secara benar. Teknologi ini

memberikan kemudahan dengan menyediakan layanan dosis, waktu serta pengingat dalam penggunaannya akan tetapi perlu upaya pengembangan terpadu dalam aplikasinya di Indonesia sehingga dapat diaplikasikan sesuai kebutuhan dalam pengawasan kepatuhan obat pada ODS.

\section{SARAN}

Inovasi teknologi (MEMS®) cap memberikan solusi dalam peran monitoring kepatuhan minum obat pada ODS. Hal ini bisa terlaksana dengan cara pengembangan alat yang memiliki fungsi sama namun dengan biaya pembuatan yang lebih terjangkau. Kemampuan sumberdaya manusia yang selalu ditingkatkan untuk menguasai teknologi dan mampu menggunakannya. Akan tetapi hal ini tidak menggantikan fungsi

perawat dalam melakukan tugas pengawasan maupun advokasi secara utuh dalam memberikan asuhan keperawatan secara holistik. Untuk itu diharapkan perawat mampu mengembangkan teknologi dalam menunjang tugas dalam pengawasan kepatuhan pengobatan pada ODS dan tetap bersinergi untuk memberikan asuhan keperawatan secara komprehensif dan holistik.

\section{DAFTAR PUSTAKA}

1. Badan Penelitian dan Pengembangan Kesehatan. Riset Kesehatan Dasar (RISKESDAS) 2013. Lap Nas 2013. 2013;1-384.

2. American Psychiatric Association. American Psychiatric Association. Diagnostic and statistical manual of mental disorders. Washingt DC. 2013;

3. Cariaga-Martinez A, Saiz-Ruiz J, Alelú-Paz R. From linkage studies to epigenetics: What we know and what we need to know in the neurobiology of schizophrenia. Vol. 10, Frontiers in Neuroscience. 2016.

4. Meltzer HY. Update on Typical and Atypical Antipsychotic Drugs. Annu RevMed[Internet]. 2013;64(1):393-406. Available from:

http://www.annualreviews.org/doi/1 0.1146/annurev-med-050911161504

5. Chesney MA. The elusive gold standard: Future perspectives for HIV adherence assessment and intervention. J Acquir Immune Defic Syndr. 2006;43(SUPPL. 1).

6. D.I. V, P.J. W, M. S, J. S, D. C, R. $\mathrm{R}$, et al. Strategies for addressing adherence problems in patients with serious and persistent mental illness: Recommendations from the 
expert consensus guidelines [Internet]. Vol. 16, Journal of Psychiatric Practice. 2010. p. 30624. Available from:

http://ovidsp.ovid.com/ovidweb.cgi

?T=JS\&PAGE=reference\&D=emed $9 \& N E W S=N \& A N=2010552630$

7. Misdrahi D, Tessier A, Husky M, Lange AC, Vrijens B, Llorca PM, et al. Evaluation of adherence patterns in schizophrenia using electronic monitoring (MEMS®): A six-month post-discharge prospective study. Schizophr Res [Internet]. Elsevier B.V.; 2017;610. Available from: http://dx.doi.org/10.1016/j.schres.2 17. 06.026

8. Acosta FJ, Ramallo-Fariña Y, Bosch E, Mayans T, Rodríguez CJ, Caravaca A. Antipsychotic treatment dosing profile in patients with schizophrenia evaluated with electronic monitoring (MEMS®). Schizophr Res [Internet]. Elsevier B.V.;2013;146(1-3):196-200.

Available from: http://dx.doi.org/10.1016/j.schres.2 13. 02.016

9. Diaz $E$, Levine $H$, Sullivan $M$, Sernyak M, Hawkins K, Cramer J, et al. Use of the Medication Event Monitoring System to estimate medication compliance in patients with schizophrenia. J Psychiatry Neurosci [Internet]. 2001;26(4):325-9. Available from: http://onlinelibrary. wiley.com/o/coc hrane/clcentral/articles/307/CN00374307/frame.html

10. Brain C, Sameby B, Allerby K, Quinlan P, Joas E, Lindström E, et al. Stigma, discrimination and medication adherence in schizophrenia: Results from the Swedish COAST study. Psychiatry Res [Internet]. Elsevier; 2014;220(3):811-7. Available from: http://dx.doi.org/10.1016/j.psychres .2014.10.016

11. Remington G, Foussias G, Agid O, Fervaha G, Takeuchi H, Hahn M. The neurobiology of relapse in schizophrenia. Schizophr Res.
2014;152(2-3):381-90.

12. Yang J, Ko YH, Paik JW, Lee MS, Han $\mathrm{C}$, Joe $\mathrm{SH}$, et al. Symptom severity and attitudes toward medication: Impacts on adherence in outpatients with schizophrenia.

Schizophr Res. 2012;134(23):226-31.

13. Videbeck SL. Psychiatric-Mental Health Nursing. Vol. 21, The Nursing clinics of North America. 2011. 530 p.

14. Matsuda M, Kohno A. Effects of the Nursing Psychoeducation Program on the Acceptance of Medication and Condition-Specific Knowledge of Patients with Schizophrenia. Arch Psychiatr Nurs [Internet]. The Authors; 2016;30(5):581-6. Available from: http://dx.doi.org/10.1016/j.apnu.20 16.03 .008

15. Townsend EA. Boundaries and bridges to adult mental health:

Critical occupational and capabilities perspectives of justice. Vol. 19, Journal of Occupational Science. 2012. p. 8-24.

16. Bright CE. Measuring Medication Adherence in Patients With Schizophrenia: An Integrative Review. Arch Psychiatr Nurs [Internet]. Elsevier Inc.; 2017;31(1):99-110. Available from: http://dx.doi.org/10.1016/j.apnu.20 16.09.003

17. Byerly MJ, Nakonezny PA, Lescouflair E. Antipsychotic medication adherence in schizophrenia. Psychiatr Clin North Am [Internet]. 2007;30(3):437-52. Available from: http://www.ncbi.nlm.nih.gov/pubme d/17720031\%0Ahttp://linkinghub.el sevier.com/retrieve/pii/S0193953X 07000494

18. Karmila, Dhian Ririn Lestari $\mathrm{H}$.

Dukungan Keluarga Dengan Kepatuhan Minum Obat Pada Pasien Gangguan Jiwa di Wilayah Kerja Puskesmas Banjarbaru. Dunia Keperawatan. 2016;4(2):8892.

19. Yamada K, Watanabe K, Nemoto 
$\mathrm{N}$, Fujita $\mathrm{H}$, Chikaraishi $\mathrm{C}$, Yamauchi $\mathrm{K}$, et al. Prediction of medication noncompliance in outpatients with schizophrenia: 2year follow-up study. Psychiatry Res. 2006;141(1):61-9.

20. McFarlane WR. Family Interventions for Schizophrenia and the Psychoses: A Review. Fam Process. 2016;55(3):460-82.

21. Higashi K, Medic G, Littlewood KJ, Diez T, Granström O, de Hert M.

Medication adherence in schizophrenia: Factors influencing adherence and consequences of nonadherence, a systematic literature review. Ther Adv Psychopharmacol. 2013;3(4):20018.

22. Lapane KL, Cameron K, Feinberg J. Technology for Improving Medication Monitoring in Nursing Homes. Adv Patient Saf From Res to Implement (Volume 4 Programs, Tools, Prod [Internet]. 2005;

Available

from: http://ezproxy.bangor.ac.uk/login?u $\mathrm{rl}=\mathrm{http}: / /$ search.ebscohost.com/logi n. aspx?direct $=$ true $\& \mathrm{db}=\mathrm{cmedm} \& A$ $\mathrm{N}=21250042 \&$ site $=$ ehost-live

23. Baril C, Gascon V, St-Pierre L, Lagacé D. Technology and medication errors: impact in nursing homes. Int J Health Care Qual Assur [Internet]. 2014;27(3):244-58. Available from: http://www.emeraldinsight.com/doi/ 10.1108/IJHCQA-03-2013-0029 
